\title{
Free at Last: Rejecting Equal Sovereignty and Restoring the Constitutional Right to Vote: Shelby County v. Holder
}

\section{Citation}

James Blacksher \& Lani Guinier, Free at Last: Rejecting Equal Sovereignty and Restoring the Constitutional Right to Vote: Shelby County v. Holder, 8 Harv. L. \& Pol'y Rev. 39 (2014).

\section{Published Version}

http://journals.law.harvard.edu/hlpr/files/2014/03/Blacksher-and-Guinier-.pdf

\section{Permanent link}

http://nrs.harvard.edu/urn-3:HUL.InstRepos:16460374

\section{Terms of Use}

This article was downloaded from Harvard University's DASH repository, and is made available under the terms and conditions applicable to Other Posted Material, as set forth at http:// nrs.harvard.edu/urn-3:HUL.InstRepos:dash.current.terms-of-use\#LAA

\section{Share Your Story}

The Harvard community has made this article openly available.

Please share how this access benefits you. Submit a story.

Accessibility 


\section{Free at Last: Rejecting Equal Sovereignty and Restoring the Constitutional Right To Vote Shelby County v. Holder}

\section{James Blacksher* and Lani Guinier**}

The Supreme Court's decision in Shelby County v. Holder ${ }^{1}$ revitalizes the oldest and most demeaning official insult to African Americans in American constitutional history. Written by Chief Justice Roberts, the majority opinion relies on an unwritten principle that Roberts calls states' "equal sovereignty" to justify the Court's decision to topple a landmark piece of legislation: Section 4 of the Voting Rights Act (hereinafter Section 4). ${ }^{2}$ Chief Justice Roberts fails, however, to acknowledge the origin story of this "equal sovereignty" principle, which can be traced back to the Court's infamous decision in Dred Scott v. Sandford. ${ }^{3}$ Shelby County is the first decision since Dred Scott to invoke the doctrine of equal sovereignty where the right to vote was involved. And, once again, just as the Court did in Dred Scott, the Court in Shelby County held that the "equal sovereignty" of the State of Alabama takes precedence over Congress's exercise of its explicit constitutional power to enforce the voting rights of the descendants of slaves.

Writing for the majority in Dred Scott, Chief Justice Taney held that black persons-slave or free-were not citizens, as they were not members of the sovereign people who founded the United States and enacted the Con-

* James Blacksher has been practicing law in Alabama since 1971. He has been counsel of record in numerous voting rights cases, including City of Mobile v. Bolden, 446 U.S. 55 (1980); Presley v. Etowah Cnty. Comm'n, 502 U.S. 491 (1992); and Sinkfield v. Kelley, 531 U.S. 28 (2000).

** Lani Guinier served from 1977 to 1981 at the Department of Justice (DOJ) as Special Assistant to Drew S. Days (Days was then Assistant Attorney General for Civil Rights; he is now a Professor Emeritus at Yale Law School). During her stint at DOJ, Guinier was asked to reorganize the Civil Rights Division's Voting Rights Section. In 1981 Guinier left DOJ to join the NAACP Legal Defense Fund (LDF), where her first assignment was to work with the Leadership Conference on Civil Rights to extend and amend the Voting Rights Act in 1982. After Congress passed and President Ronald Reagan signed the VRA as amended, Guinier successfully litigated several voting cases, including Major v. Treen, 574 F. Supp. 325 (E.D. La. 1983) and Thornburg v. Gingles, 478 U.S. 30 (1986). In 1985, in a criminal case alleging voting fraud and prosecuted before an Alabama jury by then U.S. Attorney Jefferson Beauregard Sessions III, Guinier and LDF attorney Deval Patrick (Patrick is currently Governor of Massachusetts) represented Spencer Hogue, one of the three defendants (all of whom the jury found not guilty). Guinier left LDF in 1988 to join the faculty at the University of Pennsylvania Law School. She joined the Harvard Law School faculty in 1998 and is now the Bennett Boskey Professor of Law at Harvard Law School.

${ }^{1} 133$ S. Ct. 2612 (2013).

${ }^{2} I d$. at 2618. Section 4 identified the states and localities covered by "preclearance" under Section 5. These jurisdictions were required to submit any changes in their voting laws to the United States District Court for the District of Columbia or to the United States Department of Justice before those changes could be adopted. 42 U.S.C. $§ 1973 b$ (2006).

${ }^{3} 60$ U.S. 393 (1857). 
stitution. ${ }^{4}$ To recognize blacks as citizens of the United States, Taney said, would violate the equal sovereignty of the slave states. ${ }^{5}$ Consider, for example, Article IV, Section 2 of the U.S. Constitution, known as the Privileges and Immunities Clause, which says "[t]he Citizens of each State shall be entitled to all Privileges and Immunities of Citizens of the several States." 6 Taney construed the Privileges and Immunities Clause broadly to include all the fundamental rights of citizenship, including potentially the right to vote. Since voting rights for blacks were intolerable in the slaveholding states, the Constitution of the United States, Taney concluded, could not have intended even free blacks to be citizens. ${ }^{7}$

As Yale professor Akhil Reed Amar points out, one major reason the phrase "right to vote" does not appear in the original Constitution is that the slave states "were fiercely unwilling to give the federal government wide authority over states on this sensitive issue." felt comfortable explicitly elevating "states' rights" over the right of African Americans to the "privileges and immunities" of U.S. citizenship. After all, no state could be permitted to grant free blacks citizenship, Chief Justice Taney explained in Dred Scott, because that would make black people citizens everywhere in the United States. ${ }^{9}$

From the Fourteenth and Fifteenth Amendments during Reconstruction to the twentieth and twenty-first century Civil Rights Movement's Voting Rights Act, congressional attempts to repudiate Dred Scott by enfranchising blacks were repeatedly neutered by the Supreme Court in a pattern continued by Shelby County. After the Civil War, the Fourteenth Amendment declared African Americans to be full citizens of the United States and prohibited the states from "abridg[ing] the privileges or immunities of Citizens of the United States . . .."10 Given Chief Justice Taney's broad reading of the privileges and immunities of citizenship, the Fourteenth Amendment should have guaranteed freedmen and all American citizens the right to vote. But the Supreme Court's first decisions interpreting the Fourteenth Amendment construed the Privileges or Immunities Clause so narrowly as to render it the dead letter that it remains today.

${ }^{4} I d$. at 404 .

${ }^{5} \mathrm{Id}$. at 527 .

${ }^{6}$ U.S. Const. art. IV, § 2, cl. 1.

${ }^{7}$ See Dred Scott, 60 U.S. at 416 ("It cannot be supposed that they intended to secure to them rights, and privileges, and rank, in the new political body throughout the Union, which every one of them denied within the limits of its own dominion.").

${ }^{8}$ Akhil Reed Amar, America's Unwritten Constitution: The Precedents and PrinCiPLes We Live By 183-84 (2012).

${ }^{9} 60$ U.S. at 417.

${ }^{10}$ U.S. Const. amend. XIV, $\S 1$. There is an important grammatical difference between Article IV's "Privileges and Immunities" clause and the Fourteenth Amendment's "privileges or immunities" clause (emphasis added). Article IV, Section 2 reads: "The Citizens of each State shall be entitled to all Privileges and Immunities of Citizens in the several States." U.S. Const. art IV, § 2, cl. 1 (emphasis added). By contrast, Amendment XIV, Section 1 reads: "No State shall make or enforce any law which shall abridge the privileges or immunities of citizens of the United States." U.S. Const. amend. XIV, § 1 (emphasis added). 
In the Slaughter-House Cases, for example, the Court ruled that most fundamental rights remained subject to the control of the sovereign states. ${ }^{11}$ The very next year the Court held in Minor v. Happersett that the Constitution did not grant women of any color the right to vote. ${ }^{12}$ Thus, the Supreme Court continued to use states' sovereignty, even after the Civil War, to avoid granting all Americans the right to vote. White Americans' antipathy toward enfranchising both blacks (slave or free) and the descendants of blacks (slave or free) is arguably one of the primary reasons the right to vote is still not recognized today as one of the privileges of both national and state citizenship for all Americans.

The Fifteenth Amendment, which had been adopted in 1870, was the product of Congress's realization that the states, North as well as South, were in no mood to enfranchise blacks. The Reconstruction Republicans had to settle for prohibiting state laws that 1) denied or abridged the right to vote on account of race, and 2) gave "The Congress" the "power to enforce this article by appropriate legislation." 13 This was the ground on which a century later Congress would build the Voting Rights Act of 1965, exercising its explicit power under Section 2 of the Fifteenth Amendment "to enforce this article by appropriate legislation."14 The Supreme Court's Shelby County decision does not say that Congress abused its constitutional enforcement power in enacting Section 4. ${ }^{15}$ Instead, the Shelby County majority revives the ghost of Dred Scott by ruling that Congress's enforcement power cannot be exercised in a way that violates the "equal sovereignty" of the former Confederate states.

The surest and most immediate way to repudiate the racial insult inflicted by the equal sovereignty ruling of Shelby County would be a social movement to push Congress to act. ${ }^{16}$ Such an effort, relying explicitly on

${ }^{11}$ See 83 U.S. 36, 62 (1873).

${ }_{12}^{12}$ See 88 U.S. 162,178 (1874).

${ }^{13}$ U.S. Const. amend. XV, $\S \S 1-2$. ("The right of citizens of the United States to vote shall not be denied or abridged by the United States or by any state on account of race, color, or previous condition of servitude .... The Congress shall have power to enforce this article by appropriate legislation.").

${ }^{14}$ U.S. Const. amend. XV, § 2. See also Riley v. Kennedy, 553 U.S. 406, 412 (2008) ("The VRA reflected Congress' determination that 'sterner and more elaborate measures' were needed to counteract these formidable hindrances. Sections 4 and 5 impose the most stringent of the Act's remedies. Under $\S 4(b)$, as amended, a State or political subdivision is a so-called 'covered jurisdiction' if, on one of three specified coverage dates: (1) it maintained a literacy requirement or other 'test or device' as a prerequisite to voting, and (2) fewer than $50 \%$ of its voting-age citizens were registered to vote or voted in that year's Presidential election. Section 4(a) suspends the operation of all such 'test[s] or device[s]' in covered jurisdictions. Section 5 requires covered jurisdictions to obtain what has come to be known as 'preclearance' from the District Court for the District of Columbia or the DOJ before "enact[ing] or seek[ing] to administer' any alteration of their practices or procedures affecting voting.") (citations omitted).

${ }^{15}$ See Shelby Cnty. v. Holder, 133 S. Ct. 2612 (2013).

${ }^{16}$ Sidney Tarrow defines a social movement as "collective challenges [to elites, authorities, other groups or cultural codes by people with] common purposes and solidarity, in sustained interactions with elites, opponents and authorities." Sydney G. TARrow, Power IN Movement: Social Movements and Contentious Politics 9 (1994). In the case of the 
the Fourteenth Amendment Privileges or Immunities Clause, would seek to restore Section 4 of the Voting Rights Act to exactly as it was when amended and re-enacted by Congress in 2006. ${ }^{17}$ Such an effort might ultimately gain real traction among legal academics, as more and more scholars conclude that the Supreme Court misinterpreted the Fourteenth Amendment Privileges or Immunities Clause-both in the Slaughter-House Cases (of the nineteenth century) and now in Shelby County (of the twenty-first century). ${ }^{18}$ There is, in fact, a growing "academic consensus [that] Slaughter-House was wrong-blatantly, maliciously, egregiously. (Pick your adverb.)"19

Sadly, the disinterment of Dred Scott appears not to be a simple oversight. Revitalizing the equal sovereignty principle — without acknowledging its racially discriminatory pedigree-arguably suggests that the Supreme Court majority is attempting to head off congressional reconsideration of the right to vote as one of the fundamental privileges and immunities endowed by the Constitution on every person who becomes a citizen of the United States. Such action by Congress-using its enforcement power under Section 5 of the Fourteenth Amendment-could assure African Americans, as well as all whites, Latinos, and other Americans, that threats to their full and free exercise of the franchise, and to their status as equal citizens, can be overcome through national legislation. But unless a social movement of

Voting Rights Act, a social movement would likely be a collective challenge to the Congress through the cross-racial mobilization by people with a sense of solidarity who are willing to engage in sustained interactions with elites, opponents, and authorities in order to push for an updated version of the Voting Rights Act.

${ }^{17}$ The Fannie Lou Hamer, Rosa Parks, and Coretta Scott King Voting Rights Act Reauthorization and Amendments Act of 2006, passed with a vote in the Senate of 98-0 and in the House of Representatives of 390-33, a vote that included wide support from both Democrats and Republicans. Pub. L. No. 109-246, 120 Stat. 577 (2006). Indeed, the Judiciary Committee Chairman F. James Sensenbrenner, Jr., a Republican, was one of the Act's chief sponsors.

${ }^{18}$ See, e.g., Ryan C. Williams, Originalism and the Other Desegregation Decision, 99 VA. L. Rev. 493, 560-65 (2013); Philip Hamburger, Privileges or Immunities, 105 Nw. U. L. Rev. 61, 69 (2011); Christopher R. Green, The Original Sense of the (Equal) Protection Clause; Subsequent Interpretation and Application, 19 Geo. Mason U. C.R. L.J. 219 (2009); RANDY E. Barnett, Restoring the Lost Constitution: The Presumption of Liberty 195 (2004) (arguing that the Supreme Court "set aside" the "original meaning" of the Clause); James W. Fox Jr., Re-Readings and Misreadings: Slaughter-House, Privileges or Immunities, and Section Five Enforcement Powers, 91 Ky. L.J. 67, 68 (2003) ("The long and widely held view of Slaughter-House is that Justice Miller's opinion for the Court eviscerated the Privilege or Immunities Clause and that the Clause has been a nullity ever since."); William J. Rich, Taking "Privileges or Immunities" Seriously: A Call To Expand the Constitutional Canon, 87 Minn. L. Rev. 153 (2002); Laurence H. Tribe, Saenz Sans Prophecy: Does the Privileges or Immunities Revival Portend the Future or Reveal the Structure of the Present, 113 Harv. L. Rev. 110,182 \& n.325 (1999).

${ }^{19}$ Kermit Roosevelt III, What If Slaughter-House Had Been Decided Differently?, 45 InD. L. Rev. 61, 62-63 (2011). Roosevelt's article does not engage the much discussed question whether the Bill of Rights should have been incorporated in the Fourteenth Amendment under the Privileges or Immunities Clause instead of the Due Process Clause, nor the question of whether longstanding equal protection jurisprudence should be re-evaluated under the Privileges or Immunities Clause. See, e.g., Dale E. Ho, Dodging a Bullet: McDonald v. City of Chicago and the Limits of Progressive Originalism, 19 WM. \& MARY BILL RTS. J. 369 (2010); Jeffrey Rosen, Translating the Privileges or Immunities Clause, 66 GEO. WASH. L. REv. 1241 (1998). 
academics, lawyers, and an aroused people emerges to push Congress to recover the Fourteenth Amendment Privileges or Immunities Clause, that Clause-which holds the promise of a fundamental right to vote-shall remain virtually a dead letter in constitutional jurisprudence. ${ }^{20}$

This article proceeds as follows. First, we describe the majority and dissenting opinions in Shelby County v. Holder. Then we examine the roots of Chief Justice Roberts's "equal sovereignty" principle in Dred Scott v. Sandford to show how the original Privileges and Immunities Clause made it necessary for the Supreme Court to deny the descendants of African slaves citizenship rights in order to protect the Southern states. A review of the Slaughter-House Cases and Minor v. Happersett follows to show how the Supreme Court had to gut the Fourteenth Amendment's Privileges or Immunities Clause to preserve states' control of voting rights and to prevent blacks as United States citizens from being protected by a constitutional right to vote. The final sections of this article summarize the familiar history of black disfranchisement by the former Confederate states, Congress's eventual use of anti-discrimination provisions in the Fourteenth and Fifteenth Amendments to combat voting discrimination, and how the recent Shelby County decision forces Congress to consider restoring its own power under the Fourteenth Amendment Privileges or Immunities Clause to reject the racially tainted judicial doctrine of states' equal sovereignty and to enforce a national right to vote for all American citizens.

\section{SHELBy COUNTY V. HoldeR}

Chief Justice Roberts's opinion for the Court's majority in Shelby County holds that Section 4 of the Voting Rights Act is unconstitutional. But that holding is not based on a judicial claim that Congress, in enacting the 2006 Voting Rights Act, exceeded its enforcement powers under Section 2 of the Fifteenth Amendment. It is not based on a violation of any specific provision of the Constitution at all. Instead, the majority holds that Section 4 of the Voting Rights Act is unconstitutional because, by requiring only some of the states to obtain federal preclearance before implementing changes to their policies and practices affecting voting, it violates not a Constitutional imperative but a mere "tradition": "our historic tradition that all the States enjoy equal sovereignty." 21

${ }^{20}$ See, e.g., Hamburger, supra note 18 , at 68 .

${ }^{21}$ Shelby Cnty. v. Holder, 133 S. Ct. 2621 (2013) (quoting Nw. Austin Mun. Util. Dist. No. One v. Holder, 557 U.S. 193, 202 (2009)). Chief Justice Roberts's claim of a "historic tradition" of equal sovereignty relies almost exclusively on poorly supported dicta from his own opinion four years earlier in Northwest Austin. That case challenged the constitutionality of Section 5 preclearance, but the Court expressly declined to address this constitutional question, resolving the case on other, statutory grounds. See Nw. Austin, 557 U.S. at 193, 211. Nonetheless, Chief Justice Roberts also wrote extensive dicta regarding his "constitutional concerns" about Section 5's selective preclearance scheme. Id. at 201-06. Other than the recent Northwest Austin dicta, all the precedent cited to support Shelby County's claim of a historic tradition of equal sovereignty involved conditions attached to the admission of new 
The coverage formula in Section 4 relied on the use of voting tests and low voter registration and turnout data in 1965 to target the states with a long history of "actual voting discrimination," primarily the former Confederate states that after Reconstruction segregated and disfranchised their black citizens. ${ }^{22}$ No one questions that, throughout their history, the Southern states did not want blacks to vote. Nevertheless, the Shelby County majority held that the Section 4 formula violates the equal sovereignty principle if, "in light of current conditions," the racial disparities in registration and turnout no longer distinguish the covered states from other states. ${ }^{23}$ Justice Ginsburg's powerful dissent points out that invoking the notion of states' equal sovereignty to strike down this exercise of Congress's express power to enforce the Fifteenth Amendment sub silentio overrules South Carolina v. Katzenbach, which rejected the same equal sovereignty argument in $1966 .{ }^{24}$ She identifies the two most relevant questions that should have been answered in Shelby County: 1) did Congress have the power to reauthorize the Voting Rights Act in 2006, and 2) did Congress act "rationally" when doing so? For Justice Ginsburg, the answer to both questions is an easy yes. More importantly, she declares, the Voting Rights Act has worked where it is supposed to work. "Congress approached the 2006 reauthorization of the VRA with great care and seriousness," Ginsburg says. "The same cannot be said of the Court's opinion today."25

"Hubris," Justice Ginsburg concludes, "is a fit word for today's demolition of the VRA." 26 Indeed, "throwing out preclearance when it has worked and is continuing to work to stop discriminatory changes is like

states to the union, or border disputes stemming from the terms of state admission. See infra note 137. The only cases prior to Shelby County that had applied this principle to block federal legislation because it impacted existing states differently were Dred Scott and Prigg v. Pennsylvania, 41 U.S. 539 (1842). In Prigg, another infamous case, the Court held as unconstitutional a Pennsylvania law that criminalized the taking of blacks from the state to be placed or sold into slavery. 41 U.S. at 625. Roberts cited neither Dred Scott nor Prigg in his decisions in Northwest Austin and Shelby County. (1966))

${ }^{22}$ Shelby Cnty., 133 S. Ct. at 2625 (quoting S. Carolina v. Katzenbach, 383 U.S. 301, 330

${ }^{23}$ Id. at 2627.

${ }^{24}$ Id. at 2649 (Ginsburg, J., dissenting). Katzenbach, which first upheld the Voting Rights Act and also expressly defined the boundaries of the equal sovereignty principle, should have governed Shelby County. South Carolina had challenged the then-new statute under many theories, including that preclearance "violates the principle of the equality of States." Katzenbach, 383 U.S. at 323 . The Court only needed a single sentence to roundly reject this argument: "The doctrine of the equality of States, invoked by South Carolina, does not bar this approach, for that doctrine applied only to the terms upon which States are admitted to the Union, and not to the remedies for local evils which have subsequently appeared." $I d$. at 328-29 (emphasis added). After Katzenbach, it could not have been clearer that the equal sovereignty principle was limited exclusively to the admission of new states, and did not apply when Congress wielded its authority to protect the right to vote under the Fifteenth Amendments, as it did with the Voting Rights Act and its reauthorizations.

${ }^{25}$ Shelby Cnty., 133 S. Ct. at 2644 (Ginsburg, J., dissenting).

${ }^{26} \mathrm{Id}$. at 2648. 
throwing away your umbrella in a rainstorm because you are not getting wet." 27

\section{DRED SCOTT V. SANDFORD}

The judicial pedigree of the equal sovereignty doctrine on which Chief Justice Roberts builds his 2013 Shelby County decision stretches back to Chief Justice Roger Taney's 1857 Dred Scott opinion. In Taney's view of "confederation," each state should "have the same rights of sovereignty, and freedom, and independence, as other States." ${ }^{28}$ The equal sovereignty principle would be violated, Taney held, if the following occurred:

[A] negro, whose ancestors were imported into this country, and sold as slaves, [became] a member of the political community formed and brought into existence by the Constitution of the United States, and as such become entitled to all the rights, and privileges, and immunities, guaranteed by [Article IV, Section 2]. ${ }^{29}$

Therefore, Taney said, blacks could not be "citizens" within the meaning of the Constitution, because the Founders intended that a descendant of African slaves could never become a "constituent member" of the "people of the United States' . . . who, according to our republican institutions, form the sovereignty, and who hold the power and conduct the Government through their representatives." ${ }^{30}$ Thus the free State of Illinois could not confer the status of "citizen" on Dred Scott and his family and thereby make them citizens of either Missouri or the United States. ${ }^{31}$

The equal sovereignty principle Chief Justice Taney elaborated in Dred Scott was an attempt to settle once and for all the great question of whether Congress had the power to prohibit slavery in new states created after the original thirteen states ratified the Constitution. This issue threatened to stalemate the Constitutional Convention in 1787, and its resolution was postponed by a statutory compromise. Delegates temporarily adjourned the Philadelphia Convention and rushed to New York to take their seats in the Continental Congress, where they enacted the famous Northwest Ordinance of $1787 .{ }^{32}$ The Northwest Ordinance explicitly prohibited slavery in the territories west of the Allegheny Mountains and north of the Ohio River, but was silent about slavery in Southern states' western territories. New states to be created out of the Northwest Territory would be admitted on an "equal footing" with the original states, the Ordinance provided, on condition that

${ }^{27} I d$. at 2650.

${ }^{28}$ Dred Scott v. Sandford, 60 U.S. 393, 433 (1857).

${ }^{29} \mathrm{Id}$. at 403 .

${ }^{30} \mathrm{Id}$. at 404 .

${ }^{31} I d$. at $405-06$.

${ }^{32}$ George William Van Cleve, A Slaveholders' Union: Slavery, Politics, and the Constitution in the Early Republic 154 (2010). 
the new state constitutions and governments were "in conformity to the principles contained in these Articles." ${ }^{33}$ Did that mean the new state constitutions must prohibit slavery? That question raged in Congress right up to the Civil War. ${ }^{34}$ Did Congress have power statutorily to prohibit slavery in new states north of the Ohio River and in territories and new states south of the Ohio River? Or did "equal footing" mean that new states could choose for themselves whether to legalize or prohibit slavery, just as the original thirteen states had done? The slave states stood four-square behind "equal footing." 35 Many in the free states insisted on Congress's statutory power to limit the expansion of slavery, while others were willing to compromise by allowing new states to exercise "popular sovereignty" to choose whether to legalize slavery. ${ }^{36}$ This was the inflammatory issue that led to the Missouri Compromise of 1819-21, which statutorily prohibited slavery in territories within the Louisiana Purchase north of $36^{\circ} 30^{\prime}$ latitude. ${ }^{37}$ The Dred Scott case was the first in which the Supreme Court squarely addressed the question of whether Congress had such statutory power over slavery. Its answer was no, and the Court declared the Missouri Compromise unconstitutional.

Chief Justice Taney drew the textual source of the Dred Scott equal sovereignty principle from the Privileges and Immunities Clause, also known as the Comity Clause, ${ }^{38}$ which states, "[t]he Citizens of each State shall be entitled to all Privileges and Immunities of Citizens of the several States." ${ }^{39}$ In antebellum America, this pre-Fourteenth Amendment Privileges and Immunities Clause presented a dilemma for the slaveholding states, because its application suggested that free blacks, solely by virtue of their state citizenship, should enjoy the same rights and privileges claimed by whites, including the right to vote. This created a crisis when Congress passed the Second Missouri Compromise in $1821,{ }^{40}$ which shifted the debate between pro-slavery and anti-slavery forces to the question of whether free blacks could ever be citizens of the United States. ${ }^{41}$

The position of the Southern states was that no black person, slave or free, could be a "citizen" within the meaning of the Constitution because, as

${ }^{33} I d$. at 155 .

${ }^{34} \mathrm{Id}$. at 158 ("Adoption of the Northwest Ordinance during the Convention was a planned, coordinated action that resolved a stalemate that had continued for three years in the Continental Congress by dividing the entire western territory of the United States into two territorial areas: one in which slavery was prohibited and another in which slavery's fate was nominally left to future decisions by Congress.”).

${ }^{35} I d$. at $155-56$.

${ }^{36} I d$. at $211-12$.

${ }^{37}$ See id. at 225-66.

${ }^{38}$ See supra note 10 (distinguishing the Article IV Privileges and Immunities Clause from the Fourteenth Amendment Privileges or Immunities Clause).

${ }^{39}$ U.S. Const. art. IV, § 2.

${ }^{40}$ Missouri Compromise, Res. of Mar. 2, 1821, 3 Stat. 645. Congress accepted the first Missouri constitution even though it contained a provision that barred free blacks from entering the state. The compromise prohibited that provision from being construed to exclude "any citizen, of either of the states in this Union . . . from the enjoyment of any of the privileges and immunities to which such citizen is entitled under the constitution of the United States."

${ }^{41}$ Hamburger, supra note 18 , at 70. 
the Kentucky Supreme Court held, blacks were "a degraded race . . . [and] under the constitution and laws of the United States, they can not become citizens of the Unites States." 42 To drive home the danger of considering free blacks to be citizens, the Southern states defined broadly the "privileges and immunities" guaranteed to citizens of the United States by Article IV, Section 2, to embrace all "fundamental" rights, including the right to vote, as Justice Bushrod Washington had said in Corfield v. Coryell. ${ }^{43}$ This fundamental rights strategy had its desired effect (i.e. it helped turn many Northern whites against black citizenship), because negro suffrage was unpopular in the Northern states and in the new federal territories, as well as in the South. ${ }^{44}$ So, to make black citizenship more palatable in the North, antislavery advocates defined the Article IV Privileges and Immunities Clause narrowly, so as not to include the right to vote. Perversely, the champions of free blacks' status as citizens of the United States found it necessary to read the right to vote out of the Constitution.

The debate over whether blacks could be citizens of the United States was brought to a head in Dred Scott. The pro-slavery majority of the Court held that the descendants of slaves could never be citizens within the meaning of the Constitution of the United States and based this decision on the openly racist equal sovereignty argument of the Southern states. ${ }^{45}$

Dred Scott had been taken by his "owner" out of Missouri to reside in the free state of Illinois and in Wisconsin territory, where slavery was forbidden. Then they returned to the slave state of Missouri. The Privileges

${ }^{42}$ Amy v. Smith, 11 Ky. 326, 334 (1822).

${ }^{43} 6$ F. Cas. 546, 551-52 (C.C.E.D. Pa. 1823) (No. 3,230).

${ }^{44}$ See Hamburger, supra note 18 , at 94 ("[N]othing gave a sharper edge to these arguments than to say that the rights to vote and hold office were essential or fundamental rights of citizenship. This made political rights a measure of citizenship. From this perspective, even many free blacks who enjoyed citizenship in their own states were not citizens, whether state or federal, for purposes of the [Privileges and Immunities] Clause.").

${ }^{45}$ Delivering the opinion of the Court, Chief Justice Taney held that the equal sovereignty of the slaveholding states would be offended if another state could introduce persons "in this new political family, which the Constitution brought into existence, but were intended to be excluded from it." 60 U.S. at 406 . The principle of equal sovereignty was the basis for the concurring opinions as well.

As a practical illustration of the principle, we may refer to the legislation of the free States in abolishing slavery, and prohibiting its introduction into their territories. Confessedly, except as restrained by the Federal Constitution, they exercised, and rightfully, complete and absolute power over the subject. Upon what principle, then, can it be denied to the State of Missouri? The power flows from the sovereign character of the States of the Union; sovereign, not merely as respects the Federal Government - except as they have consented to its limitation - but sovereign as respects each other.

60 U.S. at 459 (Wayne, J., concurring) (emphasis added). "This perfect equality and entire independence of all distinct States is a fundamental principle of public law." 60 U.S. at 484 (Daniel, J., concurring). " 'The Declaration of Independence was not,' says Justice Chase, 'a declaration that the United Colonies jointly, in a collective capacity, were independent States, ... but that each of them was a sovereign and independent State; that is, that each of them had a right to govern itself by its own authority and its own laws, without any control from any other power on earth.'” 60 U.S. at 502 (Campbell, J., concurring) (citations omitted). 
and Immunities Clause says that whatever rights of citizenship a person enjoys in one state must be respected by "the several States." 46 So if Dred Scott had been a "citizen" of Illinois and the Wisconsin territory, didn't the Privileges and Immunities Clause make him a "citizen" of Missouri as well?

Taney sought to avoid such a result, which would have been intolerable to the slave states, by distinguishing ordinary state citizenship from "citizen" within the meaning of the Article IV Privileges and Immunities Clause. He said:

In discussing this question, we must not confound the rights of citizenship which a State may confer within its own limits, and the rights of citizenship as a member of the Union. It does not by any means follow, because he has all the rights and privileges of a citizen of a State, that he must be a citizen of the United States. He may have all of the rights and privileges of the citizen of a State, and yet not be entitled to the rights and privileges of a citizen in any other State. ${ }^{47}$

To be a "member of the Union" meant being a "citizen of the United States." And this constitutional status of citizen, according to Taney's rigidly originalist theory, is limited to those persons who at the founding "formed the sovereignty and framed the Constitution." $48 \mathrm{He}$ held that " $[t]$ he duty of the court is, to interpret the instrument they have framed, with the best lights we can obtain on the subject, and to administer it as we find it, according to its true intent and meaning when it was adopted." ${ }^{49}$

Thus Chief Justice Taney sought to resolve the great antebellum question about the meaning of "citizens" in the Article IV Privileges and Immunities Clause by insisting that in the 1787 Constitution "citizen" was synonymous with the "people" in "We the people" upon whose sovereignty the Constitution stands. ${ }^{50}$ And, he contended, if citizen and sovereign people were the same thing, the Founders clearly did not intend to include slaves and their descendants in the definition of either term. ${ }^{51}$ Persons of African heritage "were at that time considered as a subordinate and inferior class of beings, who had been subjugated by the dominant race, and, whether emancipated or not, yet remained subject to their authority, and had no rights or privileges but such as those who held the power and the Government might choose to grant them." 52 This meant, according to Taney, that even free blacks "were not intended to be included ... under the word 'citizens' in the Constitution, and can therefore claim none of the rights and privileges which

\footnotetext{
${ }^{46}$ U.S. Const. art. IV, $§ 2$.

${ }^{47}$ Dred Scott, 60 U.S. at 405.

${ }^{48} I d$.

${ }^{49} I d$.

${ }^{50} \mathrm{Id}$. at 404 .

${ }^{51}$ Id.

${ }^{52}$ Id. at 404-05 (emphasis added).
} 
[Article IV, Section 2 of] that instrument provides for and secures to citizens of the United States." ${ }_{53}$

The "large slaveholding states," Taney said, would never have agreed to the 1787 Constitution if it had given Congress the power to make blacks members of the sovereign people. ${ }^{4}$ So, in Taney's view, when a state gave free black persons any rights enjoyed by its white citizens, those were merely the only rights and privileges that the sovereign people of that state "might choose to grant them." It gave the Africans and their descendants no share of the sovereignty of the state and no share of the derivative sovereignty of the United States. ${ }^{55}$

Native Americans who renounced their tribal sovereignty and immigrants from foreign countries could be naturalized as provided by Congress and "become citizens of a State, and of the United States . . . entitled to all the rights and privileges" provided by Article IV, because they came to full American citizenship as free peoples. ${ }^{56}$ By contrast, said Taney, "a perpetual and impassable barrier was intended to be erected between the white race and the one which they had reduced to slavery," and, regardless of whether the negro was slave or free, this permanent exclusion from the sovereign people of the United States, "this stigma, of the deepest degradation, was fixed upon the whole race." ${ }^{57}$

Justice Curtis's dissent in Dred Scott repeated the anti-slavery argument that free blacks could be citizens under Article IV, Section 2, without taking the position, unpopular with whites in both North and South, that black suffrage was one of the privileges and immunities of citizenship. He wrote, "though . . . I do not think the enjoyment of the elective franchise essential to citizenship, there can be no doubt it is one of the chiefest attributes of citizenship under the American Constitutions; and the just and constitutional possession of this right is decisive evidence of citizenship." ${ }^{58}$ Chief Justice Taney repudiated Justice Curtis's narrow definition of the privileges and immunities of citizenship by repeating the in terrorem pro-slavery interpretation of the Article IV Privileges and Immunities Clause..$^{59}$ Taney pointed to the plain text and said Justice Curtis's crabbed reading of Article IV, Section 2 "overlooks the language of the provision." ${ }^{60} \mathrm{He}$ acknowledged the obvious point that, in 1857 , women, minors, and males without property "cannot

${ }^{53} \mathrm{Id}$. at 404.

${ }^{54} \mathrm{Id}$. at $416-17$.

${ }^{55}$ See Don E. Fehrenbacher, Slavery, Law, and Politics: The Dred Scott Case in Historical Perspective 187 (1981) ("Here we are introduced to a fundamental assumption underlying Taney's argument, summed up in the words, 'whether emancipated or not.' All blacks, according to his view, stood on the same ground. Emancipation made no difference. The status of the free Negro was fixed forever by the fact that he or his ancestors had once been enslaved.").

${ }^{56}$ Dred Scott, 60 U.S. at 404.

${ }^{57} \mathrm{Id}$. at 409 (emphasis added).

${ }^{58}$ Id. at 581 (Curtis. J., dissenting) (emphasis added).

${ }^{59}$ See id. at 422.

${ }^{60} I d$. 
vote or hold the office, yet they are citizens." ${ }^{1}$ This disability did not exclude any such white person from being "a member of the community who form the sovereignty, although he exercises no share of the political power." 62 Some states may even give the franchise "to free negroes and mulattoes, but that does not make them citizens of the State, and still less of the United States, [and the Privileges and Immunities Clause] does not apply to them." 63

Taney then dismissed the distinction anti-slavery advocates made between political rights and civil rights ("mere rights of person"). ${ }^{64} \mathrm{He}$ agreed that the Privileges and Immunities Clause protected only the civil rights of "citizens of a State who are temporarily in another State without taking up their residence there," not the political rights of voting and holding office..$^{65}$ "For a citizen of one State has no right to participate in the government of another." 66 But it would be intolerable and contrary to the founders' intentions to bestow even civil rights on black visitors to slave states, said Taney. ${ }^{67}$ And here was the clincher: if the term "citizens" under the Privileges and Immunities Clause was construed to include blacks, when a black resident of a free state moved his domicile to another state, he would be clothed by the Constitution "with all the privileges and immunities which belong to citizens of the State," 68 including, by clear implication, the right to vote. "[T]hey would hold these privileges and immunities under the paramount authority of the Federal Government, and its courts would be bound to maintain and enforce them, the Constitution and laws of the State to the contrary notwithstanding." ${ }^{69}$ In other words, according to Taney, acknowledging the citizenship of free blacks under the Constitution would be an intolerable violation of states' rights to equal sovereignty.

\section{The Fourteenth Amendment}

The Dred Scott decision was one of the leading causes of both the Civil $\mathrm{War}^{70}$ and the post-War adoption of the Citizenship and Privileges or Immu-
${ }^{61} I d$.
${ }^{62} \mathrm{Id}$.
${ }^{63} I d$.
${ }^{64} I d$.
${ }^{65} I d$.
${ }^{66} I d$.
${ }^{67}$ See id. at $422-23$.
${ }^{68}$ Id. at 423 (emphasis added).
${ }^{69} \mathrm{Id}$.

${ }^{70}$ Don Fehrenbacher rejected the suggestion that the Dred Scott decision was the sine qua non of the Civil War. "Yet it was a conspicuous and perhaps integral part of a configuration of events and conditions that did produce enough changes of allegiance to make a political revolution and enough intensity of feeling to make that revolution violent." FeHrENBACHER, supra note 55, at 294 . 
nities Clauses in Section 1 of the Fourteenth Amendment. ${ }^{71}$ In the debates leading up to passage of the Fourteenth Amendment, "controversy centered on Negro suffrage as a vital element in a Reconstruction settlement with the South." 72 The Radical Republicans who led the 39th Congress that opened in December 1865 were driven by "the utopian vision of a nation whose citizens enjoyed equality of civil and political rights, secured by a powerful and beneficent national state." 73 Committed champions of the freedmen were able to get Congress to enfranchise blacks by statute in the District of Columbia and in the federal territories, and to require the former Confederate states to include black suffrage in their state constitutions as a condition for readmission to Congress. ${ }^{74}$

But the 1867 state elections convinced the ruling Republicans that federal imposition of black suffrage would be unacceptable to the Northern states, in many of which referenda on granting blacks the right to vote had been defeated. ${ }^{75}$ As Professor Amar politely puts it, "[i]n 1866, the nation was not ready for a rule that every state, in the North as well as the South, must allow blacks to vote equally." 76 So the drafters of the Fourteenth Amendment compromised by including in Section 2 a clause that would reduce representation in Congress for any state that denied the right to vote to "any of the male inhabitants of such State." 77 This provision tacitly acknowledged that some states, even under the threat of such penalty, would continue denying their black citizens the vote. ${ }^{78}$

The insertion of the word "male" in Section 2 was an intentional snub towards the cause of women's suffrage. "Black suffrage and women's suffrage were closely linked issues everywhere in the 1860s and in the South well into the twentieth century . . .."79 The suffragists had hitched their wagon to the abolitionist movement, and after the Civil War it was women who urged the governing Republicans to guarantee universal, federally enforceable voting rights. Elizabeth Cady Stanton rejected the principle that the franchise was a "gift of society" along with any suggestion that "women

${ }^{71}$ See Saenz v. Roe, 526 U.S. 489, 502 n.15 (1999); see also McDonald v. City of Chicago, 130 S. Ct. 3020, 3060 (2010) (Thomas, J., concurring) ("The meaning of $\S 1$ 's [second] sentence has divided this Court for many years.").

${ }^{72}$ William Gillette, The Right To Vote: Politics and the Passage of the FifTEENTH AMENDMENT 22 (1965).

${ }^{73}$ Eric Foner, Reconstruction: America's Unfinished Revolution, 1863-1877 230 (2002).

${ }^{74}$ See Gillette, supra note 72 , at $30-31$.

${ }^{75}$ In 1867, Republicans lost elections for state offices in Connecticut, Maine, California, Ohio, New Jersey, New York, and Pennsylvania. "Because of the size of the turnout in Ohio and because referendums on Negro suffrage went down in decisive defeat in Ohio, Kansas, and Minnesota, not to mention the discussion of it elsewhere, Republican losses were widely interpreted as repudiating extension of Negro suffrage in the North." Id. at 32-33.

${ }^{76}$ AMAR, supra note 8, at 187.

77 U.S. CONST. amend. XIV, § 2.

${ }^{78}$ See Alexander Keyssar, The Right To Vote: The Contested History of DemocRACY IN THE United States 90-91 (2000).

${ }^{79} \mathrm{Id}$. at 173 . 
and negroes" should be enfranchised "as women and negroes, and not as citizens of a republic." 80 But most Republicans feared that an initiative to give women the vote would undermine their efforts to enfranchise black males, and their calculated decision to sever the two causes infuriated the suffragists, some of whom responded with racist rhetoric of their own. ${ }^{81}$

The Section 2 compromise had an impact on Section 1 of the Fourteenth Amendment as well, which made "[a]ll persons born or naturalized in the United States . . citizens of the United States and of the State wherein they reside," and which prohibited states from "abridg[ing] the privileges or immunities of citizens of the United States . . ." 82 Section 1 clearly overruled the holding in Dred Scott that persons of African descent could never be citizens of the United States, and it gave Congress the power to enforce the privileges and immunities of national citizenship. ${ }^{83}$ But it left unresolved the longstanding antebellum question of exactly what rights would be considered privileges and immunities of U.S. citizens. Certainly, the Republican-controlled 1867 Congress, by its Section 2 compromise, was forced to agree with the defensive anti-slavery interpretation of privileges and immunities that Justice Curtis had adopted in his Dred Scott dissent, which did not include the right to vote. The bill's sponsor, Rep. Samuel Shellabarger, explained that the Fourteenth Amendment Privileges or Immunities Clause "was designed 'to enforce' the Comity Clause [Article IV Privileges and Immunities Clause], 'and aims at nothing beyond." "84 But, since it was not defined in the text of the Amendment, this left the new Privileges or Immunities Clause open to a different interpretation by a future Congress, "and Southerners in particular still worried about the inclusion of political rights." 85

\section{The Fifteenth Amendment}

Following the narrowing Republican victories in the 1868 congressional elections, Republicans in Congress were persuaded that their contin-

${ }^{80} \mathrm{Id}$. at 178.

${ }^{81}$ For example, Stanton said, "I would not trust [the colored man] with all my rights; degraded, oppressed himself, he would be more despotic with the governing power than even our Saxon rulers are." Id. at 178.

${ }^{82}$ U.S. Const. amend. XIV, $\$ 1$.

${ }^{83}$ See JaCK M. Balkin, Living Originalism 185 (2011) ("The Reconstruction Congress assumed that Congress would be the primary protector of these rights. Today we tend to think of the courts in this role, but the Reconstruction Congress had very different assumptions. The antebellum Supreme Court had often protected the interests of slaveholders, and the example of Dred Scott v. Sandford, which held that blacks could never be citizens, was still fresh in everyone's mind. The Reconstruction Congress believed that it was a far more reliable institution for protecting civil rights than the Supreme Court."). (1866)).

${ }^{84}$ Hamburger, supra note 18, at 123 (quoting Cong. Globe, 39th Cong., 1st Sess. 293

${ }^{85} \mathrm{Id}$. at 133 . 
ued rule depended on enfranchising blacks everywhere. ${ }^{86}$ With much political maneuvering, a divided Republican Party pushed the Fifteenth Amendment through Congress in 1869, and, on March 30, 1870, after a bitter campaign, it was declared ratified by the requisite twenty-nine states. ${ }^{87}$ But the price for (male) black suffrage was another compromise, one that, at least for the time being, abandoned the cause of an affirmative, universal, national right to vote, leaving the states in control of the franchise, subject only to a prohibition of racial discrimination..$^{88}$ Because of this artful dodge, "the contentious constitutional issue of federal powers over voting in the states was avoided." ${ }^{89}$ The Fifteenth Amendment would prove the worst fears of those advocates of full political equality for the descendants of African slaves..$^{90}$ Chief Justice Roberts greatly understates the matter when he says, "[t]he first century of congressional enforcement of the [Fifteenth] Amendment . . . can only be regarded as a failure." ${ }^{11}$

Passage of the Fifteenth Amendment "decisively severed" the causes of blacks' and women's suffrage..$^{92}$ The chances were missed for a national right to vote, enforceable by Congress and providing effective protection for all American citizens, when the 1867 Congress punted on the new Fourteenth Amendment Privileges or Immunities Clause. The constitutional tort that the Fifteenth Amendment established left both black citizens and the federal government with the difficult task of proving that state and local governments were guilty of racial discrimination. Viewed together, the Fourteenth and Fifteenth Amendments left much of the constitutional insult the Dred Scott Court had directed at African Americans still operative. Blacks were now citizens, but their citizen status did not unequivocally make them members of the sovereign people, of the constitutional family of the United States. The right to vote, "the just and constitutional possession [of which]," Justice Curtis had said, "is decisive evidence of citizenship," ${ }^{3}$ was still not secure.

${ }^{86}$ See Gillette, supra note 72 , at $41-45$.

${ }^{87}$ Id. at $84-85$.

${ }^{88}$ During debates over the Fifteenth Amendment when advocates of the freedmen argued that the Privileges or Immunities Clause of the Fourteenth Amendment already gave Congress the power to ban racial discrimination in voting, they were rebuffed with the argument that the antebellum interpretation of the Article IV Privileges and Immunities Clause still applied, leaving control of the franchise to the states. See Green, supra note 18, at 272-73.

${ }^{89}$ Gillette, supra note 72 , at 72 .

${ }^{90} \mathrm{Id}$. at 77 ("The Fifteenth Amendment had a limited object - first, to enfranchise the northern Negro, and second, to protect the southern Negro against disfranchisement, and it was chiefly the work of moderates in Congress. It offered too little to southern Republicans, who wanted greater protection of Negro voting and a mild guarantee of Negro officeholding; it offered even less to the many veteran antislavery northern Republicans who sought, in addition to firmer guarantees for southern Negroes, general suffrage reform and even national control of suffrage.").

${ }^{91}$ Shelby Cnty. v. Holder, 133 S. Ct. 2612, 2619 (2013) (quoting Nw. Austin Mun. Util. Dist. No. One v. Holder, 557 U.S. 193, 197 (2009)).

${ }^{92}$ KeysSAR, supra note 78 , at 179.

${ }^{93}$ Dred Scott v. Sanford, 60 U.S. 393, 581 (1956) (Curtis, J. dissenting). 


\section{The Slaughter-House CASES}

African Americans would be condemned to at least another century of exclusion from the sovereign people by the Supreme Court, which seized on Congress's missed opportunity to specify in Section 1 of the Fourteenth Amendment the privileges and immunities of United States citizenship. In the Slaughter-House Cases, ${ }^{94}$ the Court tried to close the door on future congressional reconsideration of what rights are to be included among the privileges and immunities of U.S. citizenship by defining those rights judicially. The irony of how the Court turned this constitutional trick is shameful.

The plaintiffs in the Slaughter-House Cases were white butchers who claimed, inter alia, that New Orleans gave one slaughterhouse company a monopoly that violated other butchers' rights to free labor protected by the Fourteenth Amendment Privileges or Immunities Clause. The butchers were represented by none other than John Archibald Campbell of Alabama, who had been one of the concurring Justices in Dred Scott. ${ }^{95}$ The privileges and immunities of national citizenship, Campbell argued, included "the personal and civil rights which usage, tradition, the habits of society, written law, and the common sentiments of people have recognized as forming the basis of the institutions of the country." 96 This was the broad definition of privileges and immunities in the Article IV Privileges and Immunities Clause that Campbell and his pro-slavery colleagues had invoked to defeat black citizenship. But, now, political rights were conspicuously absent from Campbell's definition.

Writing for the Court's majority, Justice Miller, an anti-slavery founder of the Iowa Republican Party ${ }^{97}$ could have called in the pro-slavery debt and given the Fourteenth Amendment Privileges or Immunities Clause the broad meaning Taney had given it, including the right to vote. But in 1873 the retreat from Reconstruction was in full swing, the movement to reunite Northern and Southern whites had begun, and even many Republicans were joining growing white hostility toward black voters and officeholders. ${ }^{98}$ Miller's opinion reflected this changing reality when it called attention to the continued denial of black suffrage by many states under the Fourteenth Amendment and the consequent adoption of the Fifteenth Amendment. ${ }^{99}$

What was Justice Miller to do? He announced a novel and strained interpretation of the Fourteenth Amendment Privileges or Immunities

9483 U.S. 36 (1873).

${ }^{95}$ The federal courthouse in Mobile, Alabama, is named in honor of Justice Campbell. Campbell reminded the Slaughter-House Court that the Fourteenth Amendment was intended to overrule Dred Scott and that it did so by establishing "ONE PEOPLE" of the United States whose "privileges and immunities cannot be abridged by State authority. . . " Id. at 53 (capitalization in original).

${ }^{96} \mathrm{Id}$. at 55 (emphasis added).

${ }^{97}$ See FonER, supra note 73, at 530.

${ }^{98}$ See id. at 524.

${ }^{99}$ See Slaughter-House Cases, 83 U.S. at 71. 
Clause. He began by rendering this sanguine-and, in retrospect, totally misplaced_-judgment: "The negro having, by the fourteenth amendment, been declared to be a citizen of the United States, is thus [by the Fifteenth Amendment] made a voter in every State of the Union." 100 Then he read into Section 1 of the Fourteenth Amendment a somewhat different "distinction between citizenship of the United States and citizenship of a State" than the distinction Chief Justice Taney had made in Dred Scott. ${ }^{101}$ Ignoring the drafters' clear statements that the new Privileges or Immunities Clause was intended to extend the guarantees of the Article IV Privileges and Immunities Clause to citizens of both the United States and the states, Miller held that the privileges and immunities of U.S. citizenship were limited to those rights explicitly set out in the 1787 Constitution. ${ }^{102}$

While acknowledging that Dred Scott's definition of citizen had been overruled, Justice Miller reaffirmed Dred Scott's "equal sovereignty principle," the states' rights claim that animates Chief Justice Roberts's opinion in Shelby County. ${ }^{103}$ That principle asserts that the "fundamental" rights inhering in citizenship are determined by each sovereign state, not by the federal government. ${ }^{104}$ The dissenting Justices pointed out that by extending Dred Scott's interpretation of the Privileges and Immunities Clause of Article IV to the Privileges or Immunities Clause of the Fourteenth Amendment the majority had "turn[ed], as it were, what was meant for bread into a stone," 105 and had rendered the Privileges or Immunities Clause "a vain and idle enactment, which accomplished nothing. . . ."106 They contended that the Fourteenth Amendment had reversed the order of citizenship in the original Constitution by making "citizenship of the United States . . the primary

${ }^{100} \mathrm{Id}$.

${ }^{101} \mathrm{Id}$. at 73 .

${ }^{102}$ Id. at 79 (quoting Crandall v. Nevada, 73 U.S. 35, 36 (1867)). They included the citizen's right "to come to the seat of government to assert any claim he may have upon that government, to transact any business he may have with it, to seek its protection, to share its offices, to engage in administering its functions. He has the right of free access to its seaports, through which all operations of foreign commerce are conducted, to the subtreasuries, land offices, and courts of justice in the several States." Id.

${ }^{103}$ See id. at 73-74.

104 See id. at 75-76. The Slaughter-House majority held that the Privileges or Immunities Clause of the Fourteenth Amendment did not "transfer the security and protection of all the civil rights . . . from the States to the Federal government." Id. at 77 . By citing Corfield $v$. Coryell, Miller implicitly endorsed Bushrod Washington's conclusion that the right to vote was one of those fundamental rights that remained subject to state sovereignty.

${ }^{105}$ Id. at 129 (Swayne, J., dissenting).

${ }^{106}$ Id. at 96 (Field, J., dissenting); see also JACK M. BALKin, Living Originalism 191 (2011) (footnotes omitted) ("Two years later, in United States v. Cruikshank [92 U.S. 542 (1875)], the Court asserted that various Bill of Rights protections were not privileges or immunities of national citizenship because these were natural rights subject to state protection. Slaughter-House, Cruikshank, and their progeny mangled the constitutional text and caused enormous mischief in subsequent years. Because the Privileges or Immunities clause was effectively read out of the Constitution, litigators and courts turned instead to the due process clause (and still later to the fundamental rights doctrines arising out of the equal protection clause) to do much of the work that the privileges or immunities clause should have performed."). 
citizenship in this country; and . . State citizenship . . . secondary and derivative, depending upon citizenship of the United States and the citizen's place of residence." 107 The dissenters embraced the pre-Civil War anti-slavery definition of privileges and immunities to include all the fundamental rights of free citizens, citing Justice Curtis's dissent in Dred Scott and Justice Washington's opinion in Corfield v. Coryell. ${ }^{108}$ But Justice Swayne acknowledged that the framers of the Fourteenth Amendment had yielded to popular opposition to black suffrage and had not intended to include the right to vote among the privileges or immunities of national citizenship that were immediately enforceable. ${ }^{109}$

\section{MINOR V. HAPPERSETT}

One year after Slaughter-House, the Supreme Court closed the door on black suffrage by holding explicitly that the Privileges or Immunities Clause in the Fourteenth Amendment did not guarantee the right to vote. Minor v. Happersett presented the question of whether the Privileges or Immunities Clause extended the franchise to women. ${ }^{110}$ The case was brought by suffragists seeking a broad interpretation of Section 1 of the Fourteenth Amendment as a judicial way to defeat the demeaning insertion of "male" in Section 2. Susan B. Anthony put the issue this way:

If we once establish the false principle, that United States citizenship does not carry with it the right to vote in every State in this Union, there is no end to the petty freaks and cunning devices that will be resorted to, to exclude one and another class of citizens from the right of suffrage. ${ }^{111}$

Unfortunately, this was exactly what the Justices in Minor v. Happersett were up to. They "were self-consciously laying the legal groundwork for decisions that would limit the ability of the federal government to prevent racial discrimination in the South as well as discrimination against workers and immigrants in the North." 112

So, without explicitly mentioning Dred Scott, the Supreme Court reaffirmed the Dred Scott holding that, like the Privileges and Immunities Clause in Article IV, the meaning of the Fourteenth Amendment Privileges

107 Slaughter-House, 83 U.S. at 112 (Bradley, J., dissenting).

${ }^{108}$ See id. at 94, 97 (Field, J., dissenting); see also id. at 122 (Bradley, J., dissenting) ("In my judgment, it was the intention of the people of this country in adopting that amendment to provide National security against violation by the States of the fundamental rights of the citizen.").

${ }^{109}$ Id. at 125-26 (Swayne, J., dissenting) ("Until [the Fifteenth] Amendment was adopted the subject to which it relates was wholly within the jurisdiction of the States. The General Government was excluded from participation.").

110 See 88 U.S. 162, 165 (1874).

${ }^{111}$ KeYsSAR, supra note 78, at 180 (footnote omitted).

${ }^{112} I d$. at $181-82$. 
or Immunities Clause must be discerned by identifying those who were allowed to vote when the Constitution was adopted in 1787. ${ }^{113}$ The Court even quoted the 1790 naturalization statute passed by Congress, which restricted citizenship to "a free white person."114 It concluded: "The [Fourteenth Amendment] did not add to the privileges and immunities of a citizen. It simply furnished an additional guaranty for the protection of such as he already had. No new voters were necessarily made by it." 115

The Minor v. Happersett Court actually turned the intent of the Fifteenth Amendment's drafters against them. The drafters had realized that the states and the nation wanted to read the right to vote out of the Fourteenth Amendment, so in 1870 they got the Fifteenth Amendment ratified to make sure everyone understood what they intended the Reconstruction Amendments to accomplish. But Chief Justice Waite left the door open for states to disfranchise blacks by indirect means. "If suffrage was one of these privileges or immunities, why amend the Constitution to prevent its being denied on account of race ... ? Nothing is more evident than that the greater must include the less, and if all were already protected why go through with the form of amending the Constitution to protect a part?"116 A constitutional "gotcha!"

White supremacy, as defined by Dred Scott, was becoming the theme that white Americans would rally around to reunite citizens of the North and South. For evidence that the Minor v. Happersett Court in 1874 read the right to vote out of the Privileges or Immunities Clause in order to pave the way for the former Confederate states to disfranchise blacks, one needs only to review the proceedings of the 1901 Alabama Constitutional Convention. John Barnett Knox, the President of the Convention, cited Minor v. Happersett to refute arguments that the federal government might interfere with provisions being placed in the Alabama Constitution to restrict black voting rights while grandfathering the right to vote for descendants of Confederate soldiers. ${ }^{117}$ Not surprisingly, then, blacks in the South would remain disfranchised until years after Congress enacted the Voting Rights Act of 1965.

${ }^{113}$ See Minor, 88 U.S. at 166.

${ }^{114} \mathrm{Id}$. at 168 .

${ }^{115} \mathrm{Id}$. at 171 .

${ }^{116}$ Id. at 175. Minor v. Happersett also held that the Article IV constitutional guarantee to every state of a "republican form of government" was no help to women (or blacks):

The guaranty necessarily implies a duty on the part of the States themselves to provide such a government. All the States had governments when the Constitution was adopted. In all the people participated to some extent, through their representatives elected in the manner specially provided. These governments the Constitution did not change. They were accepted precisely as they were, and it is, therefore, to be presumed that they were such as it was the duty of the States to provide. Thus we have unmistakable evidence of what was republican in form, within the meaning of that term as employed in the Constitution.

Id. at $175-76$.

${ }^{117}$ See R. Volney Riser, Disfranchisement, the U.S. Constitution, and the Federal Courts: Alabama's 1901 Constitutional Convention Debates the Grandfather Clause, 48 AM. J. LEGAL Hist. 237, 271-72 (2006). 


\section{The Lasting Burden of African Americans' Exclusion From the Sovereign People}

Chief Justice Roberts's Shelby County opinion says the "fundamental principle of equal sovereignty among the States" is supported by Supreme Court decisions from "[o]ver a hundred years ago," 118 but it makes no mention at all of Dred Scott, the Slaughter-House Cases, or Minor v. Happersett. Surely the Court had to be aware of the racially discriminatory origins of its "equal sovereignty" doctrine and the question the Slaughter-House Cases left unresolved about whether the descendants of slaves, who had been made citizens by Section 1 of the Fourteenth Amendment, are also members of the sovereign people of their states and of the United States. ${ }^{119}$ The constitutional context in which the Shelby County majority located its equal sovereignty principle brings to mind Chief Justice Taney's view that African Americans are still mere subjects of the Constitution, not its authors. Not full members of the sovereign people, black Americans remain merely recipients of those rights and privileges the sovereign constitutional family chooses to give them.

This constitutionally subordinate status for African Americans had long been the view of the vast majority of white Southerners through most of the twentieth century. ${ }^{120}$ States like Alabama officially embraced Jim Crow and benefitted from the disfranchisement that followed the Slaughter-House decision and the "redemption" of the former Confederate states from "black rule." ${ }^{21}$ In 1903, at the turn of the twentieth century, Justice Holmes informed black Alabamians, who had been disfranchised by that state's (still in force today) 1901 constitution, that "relief from a great political wrong, if done, as alleged, by the people of a state and the state itself, must be given by them or by the legislative and political department of the government of

118133 S. Ct. 2612, 2623 (2013).

${ }^{119}$ Henry L. Chambers, Jr., Slavery, Free Blacks and Citizenship, 43 RutGERs L.J. 487, 488 (2013). Professor Chambers explores this unresolved question by discussing the important difference between "belonging-based citizenship and rights-based citizenship." $\mathrm{He}$ reaches the same conclusion as do we: "Regardless of how American citizenship is supposed to be conceived, it appears that the Dred Scott decision has acted as a headwind against moving toward a belonging-based citizenship by shaping the manner in which African American citizenship rights are conceived and enforced." Id. at 512. And, he agrees, "[1]ittle reason exists to believe that post-Fourteenth Amendment citizenship is belonging-based. There is a difference between being a citizen and being one of us." Id. at 510 (emphasis added).

${ }^{120}$ See generally Glenn Feldman, The Irony of the Sold South: Democrats, Republicans, and Race, 1865-1944 (2013); Michael J. Klarman, From Jim Crow to Civil Rights: The Supreme Court and the Struggle for Racial Equality (2004); C. Vann Woodward, The Burden of Southern History (2008).

${ }^{121}$ See Knight v. Alabama, 787 F. Supp. 1030, 1070 (N.D. Ala. 1991) ("Redemption in all of the southern states is a term which essentially means the tossing out of Republicans and particularly blacks from public life, and the conversion of all offices to white Democratic incumbency.") (quoting Thornton Dep. at 79), aff'd in relevant part, 14 F.3d 1534 (11th Cir. 1994); see KeYsSAR, supra note 78, at 105-16. 
the United States." 122 The "people" of Alabama obviously did not include the African Americans residing there in 1901, and the citizen status provided the descendants of slaves by Section 1 of the Fourteenth Amendment entitled them only to those privileges and immunities the sovereign State of Alabama chose to grant them.

Six decades later, the Voting Rights Act became the modern response to Justice Holmes's admonition. African Americans finally obtained some relief from the political department of the United States, after many were brutally beaten by Alabama police when they attempted to march across the Edmund Pettus Bridge in Selma, Alabama. Enforcement of the Voting Rights Act of 1965 slowly led to the re-enfranchisement of Southern blacks and to the removal of many election structures that diluted their voting strength. ${ }^{123}$

The Supreme Court, however, slowed that progress by holding that the Voting Rights Act extended no rights beyond those guaranteed by the Fifteenth Amendment, ${ }^{124}$ and, in City of Mobile v. Bolden, that states were still free to retain old election schemes that denied black voters an equal opportunity to elect candidates of their choice, unless those voters could prove that the state laws were enacted for an invidious purpose. ${ }^{125}$ Congress countered Bolden by including in the 1982 amendments to the Voting Rights Act a "results" standard for Section 2.126 Then the Court narrowed the reach of Section 5 by ruling that it did not prohibit Alabama from denying equal powers to officials who had been elected by African Americans. ${ }^{127}$ The voting rights of black Etowah County citizens were not affected, the Court held, when white commissioners voted to give themselves continuing control over the road and bridge shops in their respective districts, while assigning Law-

${ }^{122}$ Giles v. Harris, 189 U.S. 475, 488 (1903) (emphases added). Giles v. Harris was a case brought by a "colored man" to affirm the constitutional right to vote for himself and "more than five thousand negroes, citizens of the county of Montgomery, Alabama." Id. at 482. Justice Holmes, writing for the Court majority, declared that if "the great mass of the white population [in Alabama] intends to keep the blacks from voting," the only effective solution would be to prepare the U.S. Supreme Court "to supervise the voting in that state by officers of the court." Id. at 488. Holmes's opinion rightly predicted that blacks who sought to exercise their Fourteenth and Fifteenth Amendment rights in states like Alabama would continue to be denied the franchise for most of the twentieth century. Id.

${ }^{123}$ See generally Quiet Revolution in the South: The Impact of the Voting Rights Аст, 1965-1990 (Chandler Davidson \& Bernard Grofman eds., 1994).

${ }^{124}$ U.S. Const. amend. XV, $\S 1$ ("The right of citizens of the United States to vote shall not be denied or abridged by the United States or by any State on account of race, color, or previous condition of servitude.").

${ }^{125}$ City of Mobile v. Bolden, 446 U.S. 55, 55-56 (1980).

12642 U.S.C. $\$ 1973$ (a) (2012) ("No voting qualification or prerequisite to voting or standard, practice, or procedure shall be imposed or applied by any State or political subdivision in a manner which results in a denial or abridgement of the right of any citizen of the United States to vote on account of race or color.").

${ }^{127}$ See Presley v. Etowah Cnty., 502 U.S. 491, 506 (1992). 
rence C. "Coach" Presley, the sole black commissioner, the duty of supervising maintenance at the courthouse. ${ }^{128}$

Now, less than seven years after the VRA's reauthorization, the Shelby County decision has struck down a core provision of the first voting rights act in which African Americans elected to Congress from all the former slaveholding states had participated. ${ }^{129}$ This direct involvement by Southern black members of Congress arguably gave special constitutional stature to the 2006 Voting Rights Act. The special constitutional stature we speak of here includes-but goes beyond - the heightened status of the Voting Rights Act emphasized by Bruce Ackerman ${ }^{130}$ and Jack Balkin. ${ }^{131}$ The Voting Rights Act also qualifies as what two scholars call a "super-statute," that is, one of the statutes that "penetrate public normative and institutional culture in a deep way" 132 and that might be considered "quasi-constitutional." 133 But, as this article argues, it is the descendants of slaves who have borne the burden of exclusion from full membership in the sovereign people, and, short of an Article V constitutional amendment, there is no other law better suited than the Voting Rights Act through which African Americans can be recognized as authors, not merely subjects, of the fundamental law of American democracy. For the first time, in 2006, the descendants of slaves, through their representatives, could be seen acting as constituent members of the sovereign people of the United States when they succeeded in exercising Congress's enforcement powers under the Reconstruction Amendments. ${ }^{134}$

${ }^{128}$ For an in-depth review of the Supreme Court decisions that sought to water down the Voting Rights Act, see J. Morgan Kousser, The Strange, Ironic Career of Section 5 of the Voting Rights Act, 1965-2007, 86 Tex. L. Rev. 667 (2008) (discussing Reno v. Bossier Parish School Bd. (Bossier II), 528 U.S. 320 (2000) and Georgia v. Ashcroft, 539 U.S. 461 (2003), and Congress's efforts to restore the Act's effectiveness).

${ }^{129}$ Artur Davis, Alabama; Corrine Brown, Alcee Hastings, and Kendrick Meek, Florida; Sanford Bishop, Jr., John Lewis, Cynthia McKinney, and David Scott, Georgia; William Jefferson, Louisiana; Bennie Thompson, Mississippi; G.K. Butterfield and Melvin Watt, North Carolina; James Clyburn, South Carolina; Alexander Green, Sheila Jackson Lee, and Eddie Bernice Johnson, Texas; and Robert Scott, Virginia, voted for the Fannie Lou Hamer, Rosa Parks, and Coretta Scott King Voting Rights Act Reauthorization and Amendments Act of 2006. The sole African-American senator in 2006, Barack Obama, was from Illinois.

${ }^{130}$ See Bruce Ackerman and Jennifer Nou, Canonizing the Civil Rights Revolution: The People and the Poll Tax, 103 Nw. U. L. Rev. 63, 94 (2009) (footnote omitted) (describing the Voting Rights Act as "a landmark statute that revolutionized traditional federal-state relationships.").

${ }^{131}$ See, e.g., Jack M. Balkin, Framework Originalism and Constitution, 103 Nw. U. L. REv. 549, 589 (footnotes omitted) ("[T]he Voting Rights Act is durable and canonical: even though parts of it must be renewed by Congress, it is currently unthinkable that Congress would not renew it."); JACK M. BALKIN, Living OriginAlism 316 (2011) ("If the Court ever does strike down the Voting Rights Act, it would mark a significant change in American politics.").

${ }^{132}$ William N. Eskridge, Jr. and John Ferejohn, Super-Statutes, 50 DukE L.J. 1215-16 (2001).

${ }^{133} I d$. at 1264 .

${ }^{134}$ See Shelby Cnty. v. Holder, 133 S. Ct. 2612, 2635 (Ginsburg, J., dissenting) (citations omitted) (discussing that the Act passed the House by a vote of 390 to 33 and by a vote of 98 to 0 in the Senate). Representatives from both political parties and from almost every one of the United States voted for the reauthorization. 
Yet the Alabama Attorney General gave his unqualified support for Shelby County's attack on Sections 4 and 5 of the Voting Rights Act. Ostensibly speaking as he did for the sovereign State of Alabama, ${ }^{135}$ he nonetheless disregarded the vigorous opposition of the elected representatives of black Alabamians. ${ }^{136}$ Thus, it appears that African Americans still are not recognized by their elected officials to be members of Alabama's sovereign people. Such circumstances were of no consequence for the Shelby County majority. None of the case authorities cited in Chief Justice Roberts's majority opinion dealt with the fundamental rights of American citizenship. ${ }^{137}$ His opinion demonstrates remarkable insensitivity to the true history of Shelby County's "equal sovereignty" principle, which shows that the ruling declaring Section 4 of the Voting Rights Act unconstitutional is based on the jurisprudence of slavery.

\section{How Congress Should Respond to Shelby County v. Holder}

Once again the former slaveholding states' claim of equal sovereignty has been invoked to foreclose recognition of the sovereign citizenship of African Americans. The great constitutional question left by Shelby County

${ }^{135}$ Ala. Code $§ 36-15-21$ (2013) ("All litigation concerning the interest of the state, or any department of the state, shall be under the direction and control of the Attorney General."); Brief of State of Alabama as Amicus Curiae Supporting Petitioner at 21, Shelby Cnty. v. Holder, 133 S. Ct. 2612 (2013) ("It is time for Alabama and the other covered jurisdictions to resume their roles as equal and sovereign parts of these United States.").

${ }^{136}$ See Brief for Alabama Legislative Black Caucus as Amicus Curiae Supporting Respondents at 2, Shelby Cnty., 133 S. Ct. 2612 ("There is a long history of decisions by this Court that disregarded the ability of the former Confederate states to suppress the votes of freedmen and their descendants. These decisions frustrated efforts of Congress to advance African Americans' rights to freedom and equality over the sovereignty claims of the Southern states.").

${ }^{137}$ See United States v. Louisiana, 363 U.S. 1 (1960) (resolving a dispute between the United States and several states over ownership of submerged lands in the Gulf of Mexico); Coyle v. Smith, 221 U.S. 559 (1911) (interpreting the 1906 act admitting Oklahoma to the Union on an equal footing with the original states); Texas v. White, 74 U.S. 700 (1868) (resolving a dispute over the disposition of federal bonds sold by the secessionist Texas government); Pollard v. Hagan, 44 U.S. 212, 230 (1845) (basing the disposition of a title dispute over alluvial land in Alabama on a holding that the original states had not granted title to their navigable shores to the United States in the Constitution, and that new states like Alabama "have the same rights, sovereignty, and jurisdiction over this subject as the original states.").

There is some shameful irony in Chief Justice Roberts's reliance on the equal sovereignty holding in this last case. The Pollard opinion traces the terms of Alabama's admission to the Union in 1819 back to the 1798 act of Congress establishing the Mississippi Territory and to the 1802 deed of cession to the federal government by Georgia of its western territories, which included most of Alabama. Id. at 222, 226. As the Pollard Court noted, Congress granted western territories ceded by Georgia all the rights and privileges of the 1787 Northwest Ordinance, "that part of it excepted which prohibited slavery. . .". Id. at 226.

The amicus brief for the Alabama Legislative Black Caucus commented on this historical background by noting that "Chief Justice John Marshall approved sub silentio Congress' authority to extend slavery into" the territory that would become the State of Alabama. See Brief of the Alabama Legislative Black Caucus, supra note 136 at 7-9. Justice Marshall reasoned that "[t]his important and dangerous contest has been compromised, and the compromise is not now to be disturbed." Id. (citing Fletcher v. Peck, 10 U.S. 87, 142 (1810)). 
is what now can African Americans (with their Latino, Asian American, Native American, and white allies) do to achieve full membership as citizens, i.e., citizens with equal access to the status and power held by the sovereign people of the states and the United States. This question transcends the enactment of new protections from discrimination in the exercise of their right to vote or the enforcement of remaining anti-discrimination protections. What can be done short of replacing the entire 1787 Constitution and the stigma of slavery it placed in the way of full citizenship for descendants of the freedmen?

The obvious starting place is revisiting the historical constitutional question on which Chief Justice Roberts's "equal sovereignty" doctrine is based. The question the Shelby County decision forces us to confront is how today we should define the privileges and immunities of United States citizenship, a task of definition that caused the Court in Dred Scott to exclude the descendants of slaves from the term "citizens" in Article IV, Section 2. It caused the Reconstruction Congress to concede that blacks' voting rights were too unpopular to be enforced under the Fourteenth Amendment Privileges or Immunities Clause. And it caused the Supreme Court to neuter the Privileges or Immunities Clause by refusing to recognize the fundamental rights of national citizenship. The only right thing to do, we contend, is to give "the privileges or immunities of citizens of the United States" their plain meaning. There can be no doubt that prevailing policies of racial and gender discrimination were the only reasons that plain meaning was not embraced in the nineteenth century.

No one today could dispute that, in Jed Rubenfeld's words, the right to vote is "the quintessential right of citizenship." 138 Akhil Reed Amar agrees that, "as a matter of ordinary language and plain meaning, the right to vote certainly can be understood as a 'privilege.'" 139 He points out that voting rights textually fit more logically under the Privileges or Immunities Clause than under the Equal Protection Clause, which "is aimed at persons, not citizens, and was understood by all as paradigmatically focused on the rights of (nonvoting) aliens-a rather awkward text for voting rights." ${ }^{140}$ But Professor Amar contends that, for the reasons cited by the Dred Scott dissenters and by the Court in Minor v. Happersett, we remain bound by the Reconstruction Congress's compromise not to include the right to vote in the Privileges or Immunities Clause. ${ }^{141}$ Professor Amar believes that the Fifteenth and Nineteenth Amendments require the courts to read the anti-discrimina-

${ }^{138}$ See Akhil Reed Amar \& Jed Rubenfeld, A Dialogue, 115 YAle L.J. 2015, 2026 (2006); accord, e.g., Bartlett v. Strickland, 556 U.S. 1, 10 (2009) ("Passage of the Voting Rights Act of 1965 was an important step in the struggle to end discriminatory treatment of minorities who seek to exercise one of the most fundamental rights of our citizens: the right to vote.").

${ }^{139}$ Amar \& Rubenfeld, supra note 138, at 2022.

${ }^{140} I d$. at 2023 .

${ }^{141} I d$. at $2022-23,2028-29$. 
tion mandate of the Fourteenth Amendment "more expansively," 142 but he stands by the original intent of the drafters to exclude political rights from the Privileges or Immunities Clause. ${ }^{143}$

Professor Rubenfeld agrees "that the framers and ratifiers of the Fourteenth Amendment did not see voting as a privilege or immunity of citizenship." 144 But he does not accept Professor Amar's argument "that later interpreters are somehow semantically barred from ruling that voting is a privilege or immunity of citizenship." 145 Rubenfeld contends that the Reconstruction framers "committed themselves and the nation to more than they bargained for," and that when we now understand that their intentions were "logically [and] morally faulty, ... a No Application Understanding [is] not binding on subsequent interpretation." 146 What counts, in his view, more than the drafters' interpretation, is "[t]he words they committed to writing." "147 Professor Amar responds with this summation of his position: "Where I think we disagree is how enactment history comes into the picture, and how much we should trust, and defer to, judicial doctrine that breaks free from that history." 148

We think Professor Rubenfeld's view is the correct one, and our question to Professor Amar is how can Americans today, understanding the "stigma, of the deepest degradation" 149 on the descendants of slaves and the subjugation of women which drove the enactment history of the Privileges or Immunities Clause, leave us any choice but to break free from the preand post-Civil War invidious disregard of the plain meaning of the Amendment's words? But we also take issue with Professor Amar's assumption that this is primarily a problem for judicial doctrine. The complex question whether the descendants of American slaves are now full partners in constitutional democracy cannot be decided by judicial fiat. "[T]he privileges or immunities of citizens of the United States" that Section 1 of the Fourteenth Amendment forbids states to "abridge" clearly begin with the democratic rights of national citizenship. Section 5 of the Fourteenth Amendment gives Congress, not the Supreme Court, the power to determine what federal stat-

${ }^{142} I d$. at 2030.

${ }^{143} I d$. at 2024 .

${ }^{144} I d$. at 2025 .

${ }^{145} I d$.

${ }^{146} I d$. at 2026 .

${ }^{147}$ Id. at 2033; see also Justice John Paul Stevens, Associate Justice, United States Supreme Court, Keynote Address at the University of Georgia Law Review Symposium: The Press and the Constitution 50 Years after New York Times v. Sullivan (Nov. 6, 2013) (quoting Justice Scalia's observation in Oncale v. Sundowner Offshore Services, Inc., 523 U.S. 75, 79 (1998), that "statutory prohibitions often go beyond the principal evil to cover reasonably comparable evils, and it is ultimately the provisions of our laws rather than the principal concerns of our legislators by which we are governed" and stating, "In my judgment that perceptive comment applies to constitutional provisions and not just to statutes.").

${ }_{148}$ Amar \& Rubenfeld, supra note 138, at 2034-35.

${ }^{149}$ See Dred Scott v. Sandford, 60 U.S. 393, 409 (1857). 
utes are "appropriate" to "enforce" those democratic rights. ${ }^{150}$ Congress' exercise of its long dormant power to enforce the Privileges or Immunities Clause in response to the Shelby County decision would not make that Clause "a dormant volcano" that invites judges "to write their personal views of appropriate public policy into the Constitution," a topic about which Judge Wilkinson has warned us. ${ }^{151}$ To the contrary, it would affirm the constitutional policy that the rights of national citizenship are to be determined in the first instance by the political branch of the federal government, ${ }^{152}$ and that the Court exceeded its authority by attempting to reintroduce an unwritten and racially tainted doctrine of states' "equal sovereignty."

The textually unjustified, discriminatorily based Supreme Court decisions in the Slaughter-House Cases and Minor v. Happersett cannot be interposed today as an objection to Congress's exercise of its enforcement power under Section 5 of the Fourteenth Amendment to interpret the Privileges or Immunities Clause as giving it the responsibility to enact laws that protect the right to vote of citizens of the United States. In his opinion for the Court in City of Boerne v. Flores, Justice Kennedy acknowledged that "[w]hen Congress acts within its sphere of power and responsibilities, it has not just the right but the duty to make its own informed judgment on the meaning and force of the Constitution." 153 City of Boerne held that Congress exceeded its Section 5 power to enforce the Due Process and Equal Protection Clauses of Section 1 of the Fourteenth Amendment when it enacted the Religious Freedom Restoration Act of 1993 (RFRA). The Court held that RFRA was an improper attempt by Congress to overrule the Court's interpretation in 1990 of the substantive rights protected by the Free Exercise Clause of the First Amendment in Employment Div., Dept. of Human Resources of Oregon v. Smith" ${ }^{154}$ and "reflect[ed] a lack of proportionality or congruence between the means adopted and the legitimate end to be achieved." 155

${ }^{150}$ See Pamela S. Karlan, The Reconstruction of Voting Rights, in RACE, REFORM, AND Regulation of the Electoral Process 34, 45 (2011) ("The framers of the Fourteenth and Fifteenth Amendments - mindful of a Supreme Court that had all too recently produced Dred Scott $v$. Sandford - 'were not content to leave the specification of protected rights to judicial decision.' Particularly in the area of political regulation, it is appropriate for Congress to play a leading role.") (quoting Michael McConnell, Institutions and Interpretation: A Critique of City of Boerne v. Flores, 111 HaRv. L. Rev. 153, 176, 182 (1997)).

${ }^{151}$ See J. Harvie Wilkinson III, The Fourteenth Amendment Privileges or Immunities Clause, 12 Harv. J.L. \& Pub. Pol'y 43, 51-52 (1989).

${ }^{152}$ See Robert G. Natelson, The Original Meaning of the Privileges and Immunities Clause, 43 GA. L. Rev. 1117, 1192 (2009) (noting that at the founding, the term "privileges" referred "to rights granted by law such as the right to vote-universally recognized as a privilege ..."). Furthermore, this would be consistent with the eighteenth century meaning of privileges and immunities as "special benefits conferred by positive law." Id. at 1146.

153521 U.S. 507, 535 (1997).

154494 U.S. 872 (1990).

${ }^{155}$ City of Boerne, 521 U.S. at 533. 
City of Boerne cannot be read to mean that the Slaughter-House Cases and Minor v. Happersett bar Congress from interpreting the Privileges or Immunities Clause according to our present-day understanding of its text to include all the fundamental rights of citizenship, including the paramount right to vote. To the contrary, Justice Kennedy's opinion reaffirms that "[i]t is for Congress in the first instance to 'determin[e] whether and what legislation is needed to secure the guarantees of the Fourteenth Amendment,' and its conclusions are entitled to much deference." 156 This article contends that those infamous 1873 and 1874 precedents have already been overruled ${ }^{157}$ by the combined weight of the Fifteenth, Nineteenth, Twenty-Fourth, and Twenty-Sixth Amendments ${ }^{158}$ and by the Supreme Court's own modern recognition of a constitutional right to vote. ${ }^{159}$ The voting rights legislation we urge Congress to enact may be the only way to place the issue back before the Court, requiring it either to agree that the Slaughter-House Cases and Minor v. Happersett are no longer good law or to explain how their destructive readings of the Privileges or Immunities Clause still control-notwithstanding the race- and gender-discriminatory rationales upon which those nineteenth century precedents were based.

The clearest, most historically appropriate response to the Shelby County decision would be congressional statutes that invoke Section 5 of the Fourteenth Amendment explicitly to overrule the Slaughter-House Cases and Minor v. Happersett and to declare that the right to vote is one of the

${ }^{156} \mathrm{Id}$. at 536 (quoting Katzenbach v. Morgan, 384 U.S. 641, 651 (1966)); see also Linda Greenhouse, A Tree Grows in Canada, N.Y. Times (Oct. 16, 2013), http://www.nytimes.com/ 2013/10/17/opinion/greenhouse-a-tree-grows-in-canada.html (noting that Justice Kennedy recently reminded us that the Constitution's framers "used words that appeal over time to our sense of justice and our sense of freedom").

${ }^{157}$ See Agostini v. Felton, 521 U.S. 203, 235 (1997) ("[The doctrine of stare decisis] is at its weakest when we interpret the Constitution because our interpretation can be altered only by constitutional amendment or by overruling our prior decisions.") (citations omitted).

${ }^{158}$ See Steven G. Calabresi \& Julia T. Rickert, Originalism and Sex Discrimination, 90 Tex. L. Rev. 1, 66-70 (2011) (arguing from an originalist perspective that the Nineteenth Amendment excised the word "male" from Section 2 of the Fourteenth Amendment and granted women full political rights under the Fourteenth Amendment, contrary to the original understanding of the Fourteenth Amendment when it was passed). That same, common sense reasoning undercuts the Court's rationale in Minor v. Happersett that the right to vote cannot be one of the privileges or immunities of national citizenship guaranteed by Section 1 because the Founders in 1787 thought the franchise could be restricted based on race, gender, and wealth. Amendments Fifteen, Nineteen, Twenty-Four, and Twenty-Six have extended the right to vote to all citizens of the United States eighteen years or older (unless, perhaps, they have participated in rebellion or crime), and consequently, Minor v. Happersett has been overruled.

${ }^{159}$ Reynolds v. Sims, 377 U.S. 533, 554 (1964) ("Undeniably the Constitution of the United States protects the right of all qualified citizens to vote, in state as well as in federal elections."); see also Jane S. Schacter, Unenumerated Democracy: Lessons From the Right to Vote, 9 U. PA J. Const. L. 457, 460 (2007) ("The march toward conceptualizing voting as protected by the Federal Constitution was not unbroken, for the language in late nineteenthcentury decisions equivocated. But the march continued nevertheless, culminating in the opinion in United States v. Classic, which decisively pronounced the right to vote to be "established and guaranteed by the Constitution." ") (quoting United States v. Classic, 313 U.S. 299, 315 (1941)). 
fundamental privileges and immunities of both state ${ }^{160}$ and national citizenship.

After all, a majority of the justices on the Supreme Court of the United States have put the issue of sovereignty squarely before us. ${ }^{161}$ By invoking the "equal sovereignty" doctrine, Chief Justice Roberts has called us back to its roots in Dred Scott, where it was the bedrock justification for white supremacy in the United States. That forces us, finally, to mobilize and push Congress to reconsider and to find overruled those decisions of the Supreme Court that reaffirmed Dred Scott's elevation of state sovereignty over national citizenship. Surely, no one today would contend that the privileges and immunities of American citizenship do not include all the fundamental rights of citizenship, especially the right to vote. The Fifteenth, Nineteenth, Twenty-Fourth, and Twenty-Sixth Amendments are more than mere restrictions on the sovereign powers of the states. By repudiating all the original disqualifications for exercising the franchise that prevailed at the nation's founding, whether based on race, gender, or poverty, in the aggregate they make it clear that all citizens of the United States who have reached the age of majority are entitled to the right to vote. ${ }^{162}$ In Justice Curtis's words from

${ }^{160}$ See Derek Shaffer, Note, Answering Justice Thomas in Saenz: Granting the Privileges or Immunities Clause Full Citizenship Within the Fourteenth Amendment, 52 Stan. L. Rev. 709,743 (2000) ("The right to vote in state elections thus seems beyond dispute and might, if need arose, be opportunely announced under the auspices of the Privileges or Immunities Clause.”).

${ }^{161}$ This could be seen as a direct response to Justice Scalia's question from the bench during oral argument in McDonald v. City of Chicago, 130 S. Ct. 3020 (2010): "[W] hy are you asking us to overrule 150, 140 years of prior law . . . ?" Transcript of Oral Argument, 2010 WL 710088 at *6-7 (quoting Justice Scalia).

${ }^{162}$ AmAR, supra note 8, at 191 ("At a certain point, it became textually, historically, and structurally apt to read each affirmation of a 'right to vote' not by negative implication but by positive implication."). Professor Amar argues that a presumptive right to vote also exists in section 2's penalty provision. He draws a counter-intuitive inference from the failure of Congress to enforce the penalty on states, some of which openly disfranchised blacks: "Section 2 says that there shall be no disfranchisement without apportionment penalty. If no apportionment penalty is actually assessed, then there can be no disfranchisement imposed upon the group of presumptive voters textually specified by section 2 [which now includes women and eighteen-year-olds]." Id. at 189. Finally, Amar makes this common-sense argument:

Ordinary Americans today broadly claim the rights to vote and to vote equally, believe that these rights are theirs, and embody these beliefs in routine practices that are nearly universally celebrated. These rights have thus become Ninth Amendment rights retained by the people and elements of proper republican government-even if they were not so when the republican-government clause and the Ninth Amendment were written.

Id. at 196.

Pamela Karlan also argues that "[t]he entire Constitution presupposes free and fair elections in which all qualified citizens can participate. The individual amendments that have expanded the electorate should be read to express a more general principle." Pamela S. Karlan, The Reconstruction of Voting Rights, in Race, Reform, and Regulation of the Electoral PRocess 42 (2011).

Professors Amar and Karlan may be correct on all these points. But congressional invocation of the Privileges or Immunities Clause would clothe all these textual and popular sources of the right to vote in the armor of national citizenship and sovereign peoplehood. "Only the 
Dred Scott, "there can be no doubt it is one of the chiefest attributes of citizenship under the American Constitutions, [so that] the just and constitutional possession of this right is decisive evidence of citizenship." 163

But it is not enough for members of Congress to proclaim the right to vote as a privilege or immunity of citizenship under the Fourteenth Amendment. The American people themselves must proclaim that the right to vote is not only a local or even state issue. The right to vote must be nationalized by a constitutional mandate that establishes the affirmative right to vote for all eligible citizens, with a special provision to ensure the equal sovereignty of the descendants of slaves as members of the constitutional family of the United States.

Mobilizing around the adoption of an amendment to the Constitution establishing the right to vote might seem like a good idea. But it overlooks the fact that an affirmative constitutional right to vote already exists in the Privileges or Immunities Clause of the Fourteenth Amendment. Moreover, restoring the right to vote as a constitutionally protected privilege or immunity of national citizenship would resoundingly free African Americans from the stigma of slavery that was the basis for ignoring the plain text of Section 1 of the Fourteenth Amendment.

What might it take, then, to get Congress to revive the Privileges or Immunities Clause of the Fourteenth Amendment? Using its Section 5 power to enforce the Privileges or Immunities Clause, Congress would have authority statutorily to enact uniform voting laws for all elections-federal, state, or local—without having to demonstrate discrimination of any kind by state laws or officials. ${ }^{164}$ For example, it could legislate all the practices and procedures governing registration (or not) of voters, ballot access, felon disfranchisement, and security against voting fraud (voter ID). ${ }^{165}$ States might retain the power to determine which state and local offices would be filled

Privileges or Immunities Clause, which guarantees rights to citizens, is suited to forbid secondclass citizenship." Green, supra note 18, at 221.

${ }^{163} 60$ U.S. at 581 (Curtis, J., dissenting).

${ }^{164}$ See JACK M. Balkin, Living Originalism 209 (2009) ("When Congress passes legislation to protect the privileges or immunities of national citizenship, it can announce that, in its view, these rights belong to all citizens. And when individuals or social movements interpret the Constitution in pressing for social change, they can make arguments that certain rights heretofore unrecognized or insufficiently protected are fundamental guarantees of citizenship that deserve special protection.").

${ }^{165}$ In December 1964, Nicholas Katzenbach, President Johnson's Attorney General, proposed exactly this kind of nationwide, uniform regulation of voting rights in the form of a proposed constitutional amendment. The language proposed in January 1965 would have read:

SECTION 1. The right of citizens of the United States to vote shall not be denied or abridged by the United States or by any State for any cause except (1) inability to meet residence requirements not exceeding sixty days or minimum age requirements, imposed by State law; (2) conviction of a felony for which no pardon or amnesty has been granted; (3) mental incompetency adjudicated by a court of record; or (4) confinement pursuant to the judgment or warrant of a court of record at the time of registration or election.

SECTION 2. The Congress shall have power to enforce this Article by appropriate legislation. 
by election or appointment, the methods of election, the times and places of elections, and related matters now subject to state control. But Congress also could exercise its Privileges or Immunities authority to monitor the voting practices and procedures of all states, or of particular states, to ensure their fairness in general, not simply whether they discriminate against classes of persons. ${ }^{166}$ Any "equal sovereignty" argument would be irrelevant. Congress would not need to demonstrate that one state discriminates more than another before requiring it to obtain federal preclearance for changes in its voting policies and practices. States could be required to comply with Section 5 of the Voting Rights Act based on a congressional determination, for example, that structural vestiges of official white supremacy persist, like Alabama's 1901 Constitution, or that racially polarized voting patterns threaten the ability of ethnic or political minorities to participate fairly and effectively in the political process. ${ }^{167}$

We would argue that one of the first such statutes aimed at rehabilitating the Privileges or Immunities Clause should be re-enactment of Section 4 of the Voting Rights Act—as it was enacted in 2006. This would be a clear determination by Congress that the "equal sovereignty" basis of the Supreme Court's decision in Shelby County v. Holder was constitutionally ultra vires, and that the equal status of all citizens of the United States outweighs any claims by the states of their equal sovereignty.

\section{Conclusion}

A constitutional right to vote has been hiding in plain sight for a century and a half, imprisoned by the hostility to blacks' and women's suffrage that caused the Supreme Court to repudiate the plain meaning of the Fourteenth Amendment Privileges or Immunities Clause and to surrender the democratic rights of United States citizens to states' claims of equal sovereignty. The Court's recent Shelby County decision forces Congress to revisit the vestiges of slavery that underlie the "equal sovereignty" claim that cannot be found in the text of the Constitution and to restore the national right to

Bruce Ackerman \& Jennifer Nou, Canonizing the Civil Rights Revolution: The People and the Poll Tax, 103 Nw. U. L. Rev. 63, 91-92 (2009).

166 The constitutional vehicle of the Privileges or Immunities Clause could enable Congress to avoid choosing between the anti-discrimination model of the Voting Rights Act and "generally applicable national laws that protect the right to vote as such of all citizens nationwide." Richard H. Pildes, Voting Rights: The Next Generation, in Race, Reform, AND ReGULation of the Electoral Process 17, 19 (Guy-Uriel E. Charles et al. eds., 2011) (emphasis omitted). It could also provide statutory encouragement of a "private protection model . . . rel[ying] on civic, partisan, and ideological groups competing for votes, attention, dollars, and affection to vigorously enforce voting rights." Guy-Uriel E. Charles \& Luis Fuentes-Rohwer, Mapping a Post-Shelby County Contingency Strategy, 123 Yale L.J. Online 131 (2013), http:/ /yalelawjournal.org/2013/06/07/charlesfuentesrohwer.html.

${ }^{167}$ See, e.g., John Harwood, Behind the Roar of Political Debates, Whispers of Race Persist, N.Y. Times, Oct. 30, 2013, at A17 ("In the 11 states of the Confederacy, Mr. Romney outpolled Mr. Obama by nine percentage points. Elsewhere, Mr. Obama won by 10 points.”). 
vote that has always resided in the plain words of the Privileges or Immunities Clause. It is up to us, the American people, to demand that Congress carry out its constitutional duty in ways that unmistakably acknowledge that the descendants of slaves are full and equal members of the sovereign people and that establish a nationwide regime of election laws capable of protecting uniformly the voting rights of all American citizens. 
